Original Article

\title{
Mitigation of cisplatin induced nephrotoxicity by casticin in male albino rats
}

\author{
Mitigação da nefrotoxicidade induzida pela cisplatina pela casticina em ratos albinos \\ machos
}

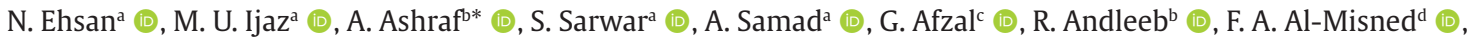 \\ K. A. Al-Ghanim ${ }^{\mathrm{d}}$ (D) Z. Z. Ahmed ${ }^{\mathrm{d}}$ (D), M. N. Riaz and S. Mahboob ${ }^{\mathrm{d} *}$ (D) \\ aUniversity of Agriculture - UAF, Faculty of Science, Department of Zoology, Faisalabad, Pakistan

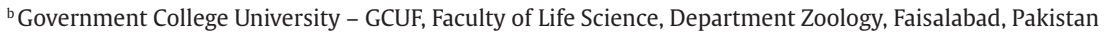 \\ Islamia University - IUB, Department of Zoology, Bahawalpur, Pakistan \\ d King Saud University - KSU, College of Science, Department of Zoology, Riyadh, Saudi Arabia \\ 'Texas A\&M University, AMU, Brazos, Texas, United States of America
}

\begin{abstract}
Cisplatin (CP) is a commonly used, powerful antineoplastic drug, having numerous side effects. Casticin (CAS) is considered as a free radical scavenger and a potent antioxidant. The present research was planned to assess the curative potential of CAS on CP persuaded renal injury in male albino rats. Twenty four male albino rats were distributed into four equal groups. Group-1 was considered as a control group. Animals of Group-2 were injected with $5 \mathrm{mg} / \mathrm{kg}$ of CP intraperitoneally. Group-3 was co-treated with CAS ( $50 \mathrm{mg} / \mathrm{kg}$ ) orally and injection of CP $(5 \mathrm{mg} / \mathrm{kg})$. Group-4 was treated with CAS $(50 \mathrm{mg} / \mathrm{kg})$ orally throughout the experiment. CP administration substantially reduced the activities of catalase (CAT), superoxide dismutase (SOD), peroxidase (POD), glutathione S-transferase (GST), glutathione reductase (GSR), glutathione (GSH) content while increased thiobarbituric acid reactive substances (TBARS), and hydrogen peroxide $\left(\mathrm{H}_{2} \mathrm{O}_{2}\right)$ levels. Urea, urinary creatinine, urobilinogen, urinary proteins, kidney injury molecule-1 (KIM-1), and neutrophil gelatinase-associated lipocalin (NGAL) levels were substantially increased. In contrast, albumin and creatinine clearance was significantly reduced in CP treated group. The results demonstrated that $\mathrm{CP}$ significantly increased the inflammation indicators including nuclear factor kappa-B (NF- $\mathrm{B}$ ), tumor necrosis factor- $\alpha$ (TNF- $\alpha$ ), Interleukin-1 $\beta$ (IL-1 $\beta$ ), Interleukin-6 (IL-6) levels and cyclooxygenase-2 (COX-2) activity and histopathological damages. However, the administration of CAS displayed a palliative effect against CP-generated renal toxicity and recovered all parameters by bringing them to a normal level. These results revealed that the CAS is an effective compound having the curative potential to counter the $\mathrm{CP}$-induced renal damage.
\end{abstract}

Keywords: cisplatin, renal damage, casticin, curative potential.

\begin{abstract}
Resumo
A cisplatina (CP) é uma droga antineoplásica poderosa, comumente usada, com vários efeitos colaterais. Casticin (CAS) é considerado um eliminador de radicais livres e um potente antioxidante. A presente pesquisa foi planejada para avaliar o potencial curativo da CAS em lesão renal induzida por PC em ratos albinos machos. Vinte e quatro ratos albinos machos foram distribuídos em quatro grupos iguais. O Grupo 1 foi considerado grupo controle. Os animais do Grupo 2 foram injetados com $5 \mathrm{mg} / \mathrm{kg}$ de PB por via intraperitoneal. O Grupo 3 foi cotratado com CAS (50 mg / kg) por via oral e injeção de CP (5 mg / kg). O Grupo 4 foi tratado com CAS (50 mg / kg) por via oral durante todo o experimento. A administração de CP reduziu substancialmente as atividades de catalase (CAT), superóxido dismutase (SOD), peroxidase (POD), glutationa S-transferase (GST), glutationa redutase (GSR), glutationa (GSH), enquanto aumentou as substâncias reativas ao ácido tiobarbitúrico (TBARS) e níveis de peróxido de hidrogênio (H2O2). Os níveis de ureia, creatinina urinária, urobilinogênio, proteínas urinárias, molécula 1 de lesão renal (KIM-1) e lipocalina associada à gelatinase de neutrófilos (NGAL) aumentaram substancialmente. Em contraste, a albumina e a depuração da creatinina foram significativamente reduzidas no grupo tratado com PC. Os resultados demonstraram que a CP aumentou significativamente os indicadores de inflamação, incluindo fator nuclear kappa-B (NF-kB), fator de necrose tumoral- $\alpha$ (TNF- $\alpha$ ), interleucina-1 $\beta$ (IL-1 $\beta$ ), interleucina-6 (IL-6) níveis e atividade da ciclooxigenase-2 (COX-2) e danos histopatológicos. No entanto, a administração de CAS apresentou um efeito paliativo contra a toxicidade renal gerada por CP e recuperou todos os parâmetros, trazendo-os a um nível normal. Estes resultados revelaram que o CAS é um composto eficaz com potencial curativo para combater o dano renal induzido por CP.
\end{abstract}

Palavras-chave: cisplatina, danos renais, casticin, potencial curativo. 


\section{Introduction}

Cisplatin (CP) is a chemotherapeutic medicine, used to cure many types of tumors efficiently such as ovarian, head, and neck tumor and testicular sarcoma (Terada et al. 2013). CP has become the most extensively used anticancer drug due to its therapeutic potential against cancer (Ijaz et al., 2020a). CP causes ROS generation and tubular inflammation, which lead to nephrotoxicity (Yang et al., 2015; Kumar et al., 2017). The main reason behind renal tubular damage is cisplatin-induced oxidative stress (Oh et al., 2017a; Saral et al., 2016). The reactive oxygen species (ROS) and reactive nitrogen species (RNS) changes the cellular structure and function (Pedraza-Chaverri et al., 2004; Divya et al., 2016). Though numerous mechanisms have been examined for nephrotoxicity caused by $\mathrm{CP}$, including inflammation and oxidative stress, the precise mechanism has not yet been well understood (Malik et al., 2016).

Biotransformation and accumulation of CP play an important role in CP-induced renal dysfunction (Perazella, 2012; Tucker and Perazella, 2018). Since many years, efforts have been made to prepare $\mathrm{CP}$ derivatives with minimum side effects which lead to the formation of oxaliplatin and carboplatin with narrow therapeutic range (Kruger et al., 2015) The other available method to decrease the nephrotoxic effects of $\mathrm{CP}$ is extensive hydration to wash out CP from kidneys (Dasari and Bernard Tchounwou, 2014). Despite urinary excretion of CP followed by extensive hydration, the side effects of $\mathrm{CP}$, especially nephrotoxicity, remain the main issue that limits the use and effectiveness of CP in cancer therapy (Pabla and Dong, 2008). One of the essential ways to decrease renal damage is the use of flavonoids which have proven to be a safer and effective strategy (Ali et al., 2007).

Plants are generally regarded as an active source of medicine (Regginato et al., 2021). Herbal medicines have become a major part of recent drug discoveries (Christen and Cuendet, 2012; Omar et al., 2020). Flavonoids are natural polyphenolics present in plants with diverse biological effects and play an essential part in detoxifying the free radicals (AlSharari et al., 2016). CAS, a natural flavonoid, is present in vegetables, spices, nuts, herbs, flowers, seeds, and stems (Miyahisa et al., 2006). CAS displays pharmacological and biological activities, i.e. anti-cancer, anti-inflammatory, and antioxidative activity (Lee et al., 2017). Therefore, the current research was planned to explore the curative ability of CAS against $\mathrm{CP}$-persuaded nephrotoxicity in male albino rats.

\section{Materials and Methods}

\subsection{Chemicals}

CP and CAS were purchased from Sigma-Aldrich (Germany).

\subsection{Animals}

Twenty-four mature male albino rats weighing 170-200g were used in this experiment. Rats were placed in the vicinity of the animal house, University of Agriculture, Faisalabad. $25 \pm 1^{\circ} \mathrm{C}$ temperature and 12 hrs. light/dark cycle was maintained in the experimental room. Cages of $54 \times 39 \times 21 \mathrm{~cm}$ size were used and 6 rats were kept in each cage. Moreover, rats were provided with tap water and standard food throughout the experiment. Before the start of the experiment, the animals were exposed to laboratory conditions for seven days. Animals were treated in compliance with the European Union of Animal Care and Experimentation (CEE Council 86/609) protocol.

\subsection{Experimental design}

Rats were divided into four groups, having 6 male rats in each and kept in different cages. The experiment was conducted for thirty days. Animals of Group-1 were given standard food throughout the experiment. Group-2 received a single injection of $\mathrm{CP}\left(10 \mathrm{mgkg}^{-1}\right)$ intraperitoneally on the day first of the trial. Group-3 was administered with $\mathrm{CP}\left(10 \mathrm{mgkg}^{-1}\right)$ injection on the first day of trial and CAS $\left(50 \mathrm{mgkg}^{-1}\right)$ orally daily till the completion of the trial. Doses were selected by following the Ijaz et al. (2020b). Rats of group- 4 were administered with regular doses of CAS (50 $\mathrm{mgkg}^{-1}$ ) orally once daily throughout the experiment. After thirty days of treatment, rats were given anesthesia, dissected and blood was collected for biological estimation of serum profile. After dissection both the kidneys were separated; one of them was packed in zipper bags and stored at $-80^{\circ} \mathrm{C}$ for biochemical analysis. Another kidney was preserved in $10 \%$ neutral formalin buffer solution for histopathological examination.

\subsection{Biochemical analysis}

The kidney was stored at $-80^{\circ} \mathrm{C}$ and homogenized in $3 \mathrm{ml}$ of PBS ( $\mathrm{pH} 7.4$ ), then centrifuged at $12000 \mathrm{rpm}$ for 15 minutes before analysis. CAT and POD activities were analyzed by following the method of Chance and Maehly (1955). The process of Kakkar et al. (1984) was followed to examine SOD activity. GST activity was evaluated according to the methodology of Habig et al. (1974). The procedure of Carlberg and Mannervik (1975) was used for the estimation of GSR activity while the GSH content was evaluated using the procedure of Jollow et al. (1974).

\subsection{TBARS and hydrogen peroxide}

$\mathrm{H}_{2} \mathrm{O}_{2}$ concentration was measured according to the procedure stated by Pick and Keisari (1981). TBARS analysis was performed by following the methodology of Iqbal et al. (1996).

\subsection{Kidney function markers}

Estimation of albumin, urea, urobilinogen, creatinine, urinary proteins, and creatinine clearance was completed by using standard diagnostic-kits, AMP diagnostic kit (AMEDA labor-diagnostic Gmbh, Austria). Urinary KIM-1 and Serum NGAL were determined according to the manufacturer's command by using KIM-1 Quantikine ELISA Kit and NGAL Quantikine ELISA Kit ( $R$ and D Systems China Co. Ltd., Changning, China). 


\subsection{Inflammatory markers assessment}

Commercially available kits were used to assess the inflammatory markers of the renal tissues. NF- $\kappa B, T N F-\alpha$, IL-6, IL-1 $\beta$ levels and COX-2 activity were determined with a rat ELISA kit (Shanghai YL Biotech Co. Ltd., China). Analyses were accomplished by following the manufacturer's instructions through ELISA Plate Reader (BioTek, Winooski, VT, USA).

\subsection{Histopathological study}

Kidney samples were preserved in $10 \%$ neutral formalin buffer solution for the fixation. Dehydration was performed with ascending grades of alcohol (80\%, $90 \%$, and $100 \%)$ and samples were transferred to cedarwood oil. After dehydration, tissues were embedded in paraplast and the blocks were prepared for microtomy. Thin slides of 3-4 mm were prepared by using a microtome and stained with Hematoxylin-eosin stain. Microphotography was conducted under a light microscope at 40X.

\subsection{Statistical study}

All numerical data collected from the experimental design were described in terms of Mean \pm SEM. A comparison test was performed to check different groups using One-way ANOVA followed by Tukey's test, and Minitab software was used. The level of significance $(\mathrm{p}<0.05)$ was used.

\section{Results}

\section{1. Effect of CAS on antioxidant enzymes activity}

The rats administered with CP displayed substantially $(\mathrm{p}<0.05)$ reduced antioxidant enzyme activities comprising CAT, SOD, POD, GST, GSR, and GSH content in contrast to the control group. Co-treatment of $\mathrm{CP}$ and CAS elevated the level of suppressed enzyme activities significantly ( $\mathrm{p}<0.05)$. While only CAS treated rats displayed antioxidant enzymes activity almost near to the control group values (Table 1 ).

\subsection{Effect of CAS on TBARS (lipid peroxidation) and $\mathrm{H}_{2} \mathrm{O}_{2}$}

TBARS and $\mathrm{H}_{2} \mathrm{O}_{2}$ levels significantly $(\mathrm{p}<0.05)$ elevated in $\mathrm{CP}$ treated rats when compared to the control group, however rats received $\mathrm{CP}+\mathrm{CAS}$ and CAS only did not show any remarkable difference in TBARS and $\mathrm{H}_{2} \mathrm{O}_{2}$ level in contrast to the control group (Table 2).

\subsection{Effects of CAS on serum and urine profile}

CP administration resulted in significant $(\mathrm{p}<0.05)$ elevation in the levels of creatinine, urea, urobilinogen, urinary proteins, KIM-1, and NGAL. Simultaneously, there was a substantial $(p<0.05)$ decline in albumin and creatinine clearance in comparison to the control group. CAS + CP concurrent treated rats showed counter effect CAS over CP by diminishing the amount of creatinine, urea, urobilinogen, urinary proteins, KIM-1, and NGAL while improved the albumin level and creatinine clearance (Table 3 ).

\subsection{Effect of CAS on inflammatory markers}

$\mathrm{CP}$ administration substantially $(\mathrm{p}<0.05)$ raised the levels of inflammatory parameters NF- $\kappa B, T N F-\alpha$, IL- $1 \beta$, IL-6, and COX-2 activities in CP treated rats compared to the control group. While CAS administration considerably $(p<0.05)$ decreased the levels of these inflammatory parameters in the cotreated rats in contrast to the $\mathrm{CP}$ treated group (Table 4).

\subsection{Effect of CAS on renal histology}

Normal histology of renal tissue was detected in the control and CAS treated group. Both groups exhibited normal glomeruli with normal distal, and convoluted tubules and Bowman's capsule. Histopathological

Table 1. Effects of casticin on the activity of CAT, SOD, POD, GSH, GSR, and GST in the kidneys of CP-treated rats.

\begin{tabular}{|c|c|c|c|c|c|c|}
\hline Groups & $\begin{array}{c}\text { CAT } \\
\text { (U/mg } \\
\text { protein) }\end{array}$ & $\begin{array}{c}\text { SOD } \\
\text { (nanomole) }\end{array}$ & $\begin{array}{c}\text { POD } \\
\text { (U/mg protein) }\end{array}$ & $\begin{array}{c}\text { GST } \\
(\mathrm{mg} / \mathrm{dl})\end{array}$ & $\begin{array}{c}\text { GSR (Nm NADPH } \\
\text { oxidized/min/mg } \\
\text { tissues) }\end{array}$ & $\begin{array}{c}\text { GSH } \\
\text { (nM/min/mg } \\
\text { protein) }\end{array}$ \\
\hline Control & $6.49 \pm 0.09 \mathrm{a}$ & $7.25 \pm 0.06^{a}$ & $5.64 \pm 0.03^{a}$ & $22.09 \pm 0.62^{a}$ & $2.94 \pm 0.04^{\mathrm{a}}$ & $14.7 \pm 0.38^{a}$ \\
\hline CP (10 mg/kg) & $2.45 \pm 0.06^{b}$ & $3.69 \pm 0.09^{b}$ & $1.90 \pm 0.02^{b}$ & $10.40 \pm 0.31^{b}$ & $0.97 \pm 0.03^{b}$ & $7.78 \pm 0.27 \mathrm{~b}$ \\
\hline $\begin{array}{l}\text { CP (10 mg/kg) + } \\
\text { CAS (50 mg/kg) }\end{array}$ & $6.22 \pm 0.04^{a}$ & $6.91 \pm 0.03^{c}$ & $5.10 \pm 0.01^{\mathrm{a}}$ & $20.49 \pm 0.39^{c}$ & $2.75 \pm 0.02^{\mathrm{a}}$ & $13.7 \pm 0.29^{c}$ \\
\hline CAS (50 mg/kg) & $6.47 \pm 0.01$ a & $7.40 \pm 0.01^{\mathrm{a}}$ & $5.61 \pm 0.04^{a}$ & $22.84 \pm 0.14^{a}$ & $3.06 \pm 0.03^{\mathrm{a}}$ & $14.6 \pm 0.19$ a \\
\hline
\end{tabular}

Values in a column having dissimilar superscripts are considerably $(\mathrm{p}<0.05)$ different from others.

Table 2. Effects of casticin on the level of TBARS and $\mathrm{H}_{2} \mathrm{O}_{2}$ in the kidneys of CP-treated rats.

\begin{tabular}{|c|c|c|}
\hline Groups & TBARS (nM/mg tissue) & $\mathbf{H}_{2} \mathbf{O}_{2}(\mu \mathrm{M} / \mathrm{min} / \mathrm{mg}$ protein $)$ \\
\hline Control & $15.36 \pm 0.42^{a}$ & $1.19 \pm 0.099^{a}$ \\
\hline CP (10 mg/kg) & $24.89 \pm 0.24^{b}$ & $5.63 \pm 0.07^{b}$ \\
\hline CP (10 mg/kg) + CAS (50 mg/kg) & $16.23 \pm 0.21^{c}$ & $1.93 \pm 0.05^{a}$ \\
\hline CAS (50 mg/kg) & $15.29 \pm 0.19^{a}$ & $1.24 \pm 0.07 \mathrm{a}$ \\
\hline
\end{tabular}

Values in a column having dissimilar superscripts are considerably $(\mathrm{p}<0.05)$ different from others. 
Table 3. Effects of casticin on the serum and urine profile in the kidneys of CP-treated rats.

\begin{tabular}{|c|c|c|c|c|}
\hline Groups & Control & $\mathrm{CP}(10 \mathrm{mg} / \mathrm{kg})$ & $\begin{array}{l}\text { CP }(10 \mathrm{mg} / \mathrm{kg})+ \\
\text { CAS }(50 \mathrm{mg} / \mathrm{kg})\end{array}$ & CAS $(50 \mathrm{mg} / \mathrm{kg})$ \\
\hline Urea (mg/dl) & $20.6 \pm 0.35^{\text {a }}$ & $66.7 \pm 0.60^{\mathrm{b}}$ & $26.6 \pm 0.32^{c}$ & $21.7 \pm 0.31^{\text {a }}$ \\
\hline Creatinine (mg/dl) & $1.94 \pm 0.06^{\mathrm{a}}$ & $4.29 \pm 0.13^{b}$ & $2.21 \pm 0.01^{c}$ & $2.04 \pm 0.04^{a}$ \\
\hline Creatinine clearance $(\mathrm{ml} / \mathrm{min})$ & $1.62 \pm 0.06^{\mathrm{a}}$ & $0.92 \pm 0.03^{b}$ & $1.53 \pm 0.01^{c}$ & $1.57 \pm 0.01 \mathrm{ac}$ \\
\hline Albumin (mg/dl) & $8.07 \pm 0.05^{\mathrm{a}}$ & $3.67 \pm 0.04 \mathrm{~b}$ & $7.91 \pm 0.02^{c}$ & $8.01 \pm 0.04$ ac \\
\hline Urobilinogen (mg/dl) & $3.66 \pm 0.03^{a}$ & $9.98 \pm 0.03^{b}$ & $4.05 \pm 0.03^{c}$ & $3.97 \pm 0.02^{\mathrm{a}}$ \\
\hline Urinary proteins (mg/dl) & $14.7 \pm 0.22^{\mathrm{a}}$ & $33.6 \pm 0.82^{b}$ & $17.0 \pm 0.08^{c}$ & $15.3 \pm 0.15^{\text {a }}$ \\
\hline Urinary KIM-1 (mg/ml) & $0.42 \pm 0.01^{\mathrm{a}}$ & $2.22 \pm 0.05^{b}$ & $1.17 \pm 0.05^{c}$ & $0.44 \pm 0.02^{\mathrm{a}}$ \\
\hline NGAL (ng/day) & $0.83 \pm 0.03$ & $2.86 \pm 0.06^{b}$ & $1.66 \pm 0.04^{c}$ & $0.76 \pm 0.04^{a}$ \\
\hline
\end{tabular}

Values in a same row having dissimilar superscripts are considerably $(\mathrm{p}<0.05)$ different from others.

Table 4. Effects of CAS on inflammatory parameters (NF-kB, TNF- $\alpha$, IL-1 $\beta$, IL-6 levels and COX-2 activities) in the kidneys of CP-treated rats.

\begin{tabular}{|c|c|c|c|c|c|}
\hline Groups & $\begin{array}{c}\text { NF-кB } \\
\text { (ng/g tissue) }\end{array}$ & $\begin{array}{c}\text { TNF- } \alpha \\
\text { (ng/g tissue) }\end{array}$ & 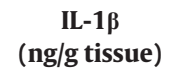 & $\begin{array}{c}\text { IL-6 } \\
\text { (ng/g tissue) }\end{array}$ & $\begin{array}{c}\text { COX-2 } \\
\text { (ng/g tissue) }\end{array}$ \\
\hline Control & $17.0 \pm 0.83^{\mathrm{a}}$ & $6.26 \pm 0.14^{\mathrm{a}}$ & $27.1 \pm 0.98^{a}$ & $5.59 \pm 0.08^{a}$ & $23.9 \pm 0.87^{\mathrm{a}}$ \\
\hline CP (10 mg/kg) & $59.5 \pm 1.17^{b}$ & $14.4 \pm 0.19^{\mathrm{b}}$ & $96.3 \pm 1.94^{b}$ & $17.7 \pm 0.45^{b}$ & $68.1 \pm 1.17^{b}$ \\
\hline $\begin{array}{l}\mathrm{CP}(10 \mathrm{mg} / \mathrm{kg})+\mathrm{CAS}(50 \\
\mathrm{mg} / \mathrm{kg})\end{array}$ & $29.6 \pm 1.35^{c}$ & $9.43 \pm 0.16^{c}$ & $39.8 \pm 1.39^{c}$ & $8.75 \pm 0.07^{c}$ & $38.1 \pm 13.35^{c}$ \\
\hline CAS (50 mg/kg) & $16.5 \pm 0.40^{\mathrm{a}}$ & $6.08 \pm 0.06^{a}$ & $26.05 \pm 1.20^{\mathrm{a}}$ & $5.54 \pm 0.06^{\mathrm{a}}$ & $23.6 \pm 0.40^{\mathrm{a}}$ \\
\hline
\end{tabular}

Values in a same column having dissimilar superscripts are considerably $(\mathrm{p}<0.05)$ different from others.

abnormalities were observed in the $\mathrm{CP}$ administered group. The malpighian body showed irregular damaged corticular segments and aggregation of necrotic cells. There was also an inflammatory cell's penetration in corticular and medullary sections, stuffing of blood vessels, stretching of tubules, and constriction of Bowman's capsule space. CP and CAS co-administration reduced the renal damages with improved glomerular degradation and inflammatory cells infiltration and normal renal tissues like the non-treated group (Figure 1).

\section{Discussion}

$\mathrm{CP}$ is commonly used to treat the several types of tumors i.e., head and neck area, testis, liver, prostate, ovary, lung, and cervix tumors (Elsherbiny et al., 2016). Nearly $30 \%$ of patients experience renal toxicity, which is the most familiar side effect restricting cisplatin medications (Farooqui et al., 2017). Some studies have indicated that ROS and immune responses are prominent mediators of CP-induced nephrotoxicity (Abdellatief et al., 2017). Plants and herbs are naturally occurring sources having a long history of medicinal value. The extraction of modern-day drugs from natural products, generally from plant origin (Afsar et al., 2016). Casticin is considered as one of the major compounds extracted from herbs (Vetrix and Viticis Fructus), and Asian countries have been using it as traditional medicine extensively since old times (Mali and Dhake, 2011).
In this experiment, a remarkable decline was observed in antioxidant enzyme activities, including CAT, SOD, POD, GSH, GSR, and GST content. CAT substantially converts the $\mathrm{H}_{2} \mathrm{O}_{2}$ into $\mathrm{H}_{2} \mathrm{O}$ and $\mathrm{O}_{2}$ and protects the cells from the oxidative damage caused by $\mathrm{H}_{2} \mathrm{O}_{2}$ and $\mathrm{OH}^{-}$(Aitken and Roman, 2008). SOD supports the conversion of $\mathrm{O}^{-2}$ into hydrogen peroxide and oxygen (Liochev and Fridovich, 2010). GSR oxidizes the glutathione disulfide by transforming it into reduced glutathione (Kaneko et al., 2002). Glutathione (GSH) protects mammalian cells against oxidative stress by minimizing levels of $\mathrm{H}_{2} \mathrm{O}_{2}$ as well as other peroxides (Deponte, 2013). GST is a multifunctional enzyme, involved in detoxification processes due to catalytic conjugation of glutathione present in it with a large number of electrophilic toxins (Tirmenstein and Reed, 1989). CP produces reactive oxygen species, containing hydroxyl radicals $\left(\mathrm{OH}^{-}\right)$and superoxide anion $\left(\mathrm{O}_{2-}\right)$, and triggers renal LPO (Mukhopadhyay et al., 2012). Earlier studies have detected the renal oxidative damage indicators, for example, escalated MDA and reduced antioxidant levels in renal tissues (Ma et al., 2017). CAS improves the damage by bringing the activities of antioxidant enzymes at normal levels. CAS possesses antioxidant properties as it is beneficial in reducing the ROS levels by raising antioxidant enzymes level (Ekinci-Akdemir et al., 2018; Ijaz et al., 2020b).

The elevated level of TBARS and $\mathrm{H}_{2} \mathrm{O}_{2}$ showed a damaging effect in the kidney of animals administered with CP. It has been documented by other authors that, $\mathrm{CP}$ persuades free radicals and produces lipid peroxidation and oxidative stress in the kidney (Sahu et al., 2011). CP produces highly reactive 


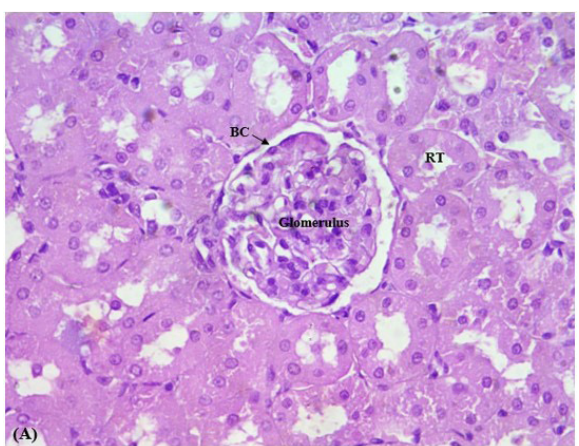

(A) Control

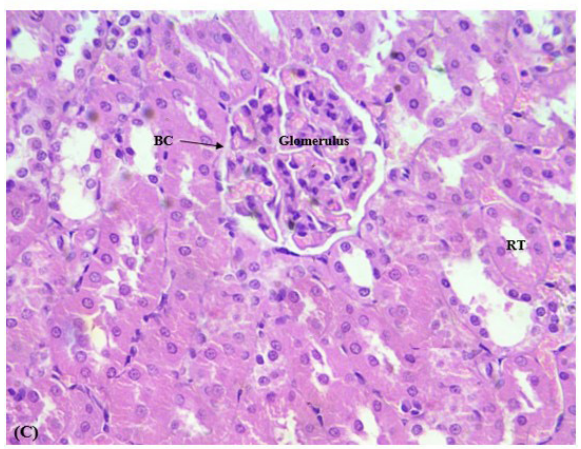

(C) CP (10mg/kg) + CAS (50mg/kg)

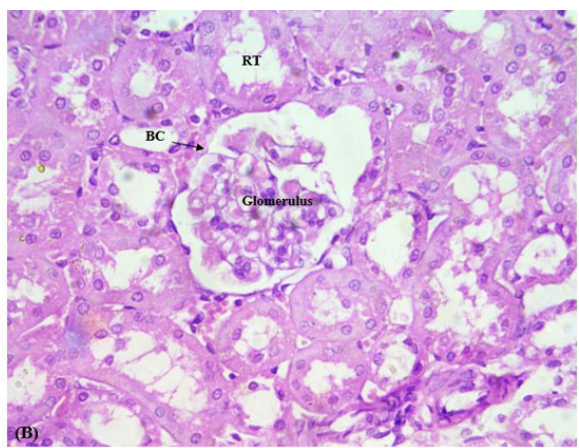

(B) CP (10mg/kg)

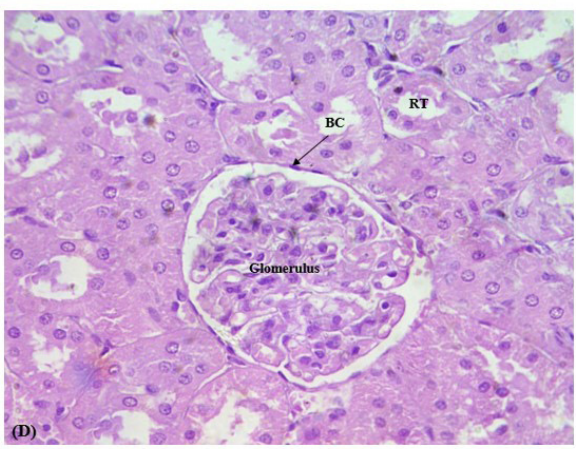

(D) CAS (50mg/kg)

Figure 1. Histopathological examination of the different groups of renal tissues. (A) Renal section of control group rats, displaying normal histological structure of glomeruli and renal tubules; (B) Renal section of $\mathrm{CP}(10 \mathrm{mg} / \mathrm{kg})$ administered rats, representing significant degenerative changes, granular deposits in their lumens and desquamation of the kidney epithelium; (C) A microphotograph of CAS $(50 \mathrm{mg} / \mathrm{kg})+\mathrm{CP}(10 \mathrm{mg} / \mathrm{kg})$ treated rats displaying reduced degenerative alterations in renal epithelium and renal tubules; (D) Renal section showing normal histological structure of glomeruli and renal tubules as in control rats treated with CAS (50 mg/kg) alone. BC; Bowman's capsule, RT; Renal tubule.

free radicals including hydroxyl and superoxide radicals that can directly interact and alter numerous components such as lipids, proteins, and other molecules and ultimately causes the death of the cell (Satoh et al., 2003). While the group received CAS and co-treatment exhibited a reduction in TBARS and $\mathrm{H}_{2} \mathrm{O}_{2}$ level. CAS administration restored the $\mathrm{H}_{2} \mathrm{O}_{2}$ and TBARS towards normal values by attenuating the production of free radicals and these results are also supported by some other investigations (Ijaz et al., 2020a) in which the CAS recovered the levels of these parameters in hepatic cells of a rat.

The concentration of serum urea urobilinogen, urinary proteins, and creatinine was significantly increased in rats treated with CP. Urine does not contain urobilinogen as a component in normal conditions (Sahreen et al., 2015); therefore, its higher level in urine indicates the abnormality of the kidney. According to Farooqui et al. (2017), CP caused renal toxicity, reduced kidney function markers, and lead towards increased concentration of blood urea and serum creatinine. Increased creatinine and urinary proteins level and reduced level of creatinine clearance and albumin are the markers for acute oxidative damage in the renal tissues (Khan et al., 2010). CAS administration normalized the concentration of these markers by diminishing ROS production and reduced renal injuries which may be due to its antioxidant potential.

CP treatment raised the levels of KIM- 1 and NGAL in treated rats. It has been reported that KIM- 1 and NGAL are the biomarkers of acute kidney injury (AKI) (Lei et al., 2018). KIM-1 is a transmembrane protein and universally accepted marker for the initial diagnosis of AKI (Khan et al., 2012). In the healthy renal tissue, it is not expressed (Aydin et al., 2011); however, it is expressed during the early stages of nephrotoxicity at lower to higher levels (Luo et al., 2016). It is also interrelated with the acuteness of renal damage. It has protein-hydrolytic zones that help to detect its urine presence (Lei et al., 2018). NGAL is a modern parameter and is freshly recognized as a member of the lipocalin family (Shin et al., 2009). NGAL is a cytosolic protein present in the blood, urine, renal, and proximal-distal tubules in the situation of nephrotoxic injury and renal ischemia (Mori et al., 2005). NGAL is expressed in the damaged glomerulus and can affect epithelial regeneration. It is normally discharged into the blood in greater extents after damage and evacuated through the urine (Ross and Kasum, 2002). CP is a cytotoxic agent which may disrupt the integrity of renal cells, that leads to increased levels of KIM-1 and NGAL. Our results are in line with previous findings by Abdelsalam et al. (2018) and Faig et al. (2018), 
who observed the substantial elevation in renal KIM-1 and NGAL levels in cisplatin-induced renal damage. Another study also reported the increase in NGAL and KIM-1 one day after a 10 $1 \mathrm{M}$ dose of CP (Oh et al., 2017b). CAS treatment decreased the levels of KIM-1 and NGAL in cotreated rats, which confirmed that CAS treatment recovered the renal injuries. Due to the mitigation of the damaged kidney tissues, the level of KIM-1 and NGAL substantially decreased in CAS treated rats.

Inflammation plays a pivotal role in $\mathrm{CP}$ associated with renal damage. In this study, $\mathrm{CP}$ treatment elevated the levels of NF- $\kappa B$, TNF- $\alpha$, IL- 6 , IL- $1 \beta$, and COX- 2 activities. $N F-\kappa B$ activation is elemental in the expression of pro-inflammatory cytokines like NF- $\kappa$ B, TNF- $\alpha$, IL- $1 \beta$, IL-6, and COX-2 that are linked with acute inflammatory responses and other ROS related disorders (Kandemir et al., 2018). NF-kB activation leads to increased secretion of TNF- $\alpha$, IL-1 $\beta$, IL-6 through gene upregulation, which contributes to acute kidney injury and progression (Lee et al., 2006; Ramesh et al., 2007). COX-2 is an inductive form of COX and an additional critical inflammation marker, which plays an important biological role in inflammation (Subbaramaiah and Dannenberg, 2003). In this analysis, the activity of COX-2 was intensified in renal tissues of $\mathrm{CP}$ treated groups which indicates the renal damage in $\mathrm{CP}$ treated rats. CAS treated rats showed decreased levels of NF- $\kappa$ B, IL- $1 \beta$, TNF- $\alpha$, IL- 6 , and COX-2 activities. This normalization may be attributed to the anti-inflammatory potential of CAS. These results solidify the anti-inflammatory role of CAS in renal tissues.

Histopathological abnormalities were observed in the CP administered group. The malpighian body showed irregular damaged corticular segments and aggregation of necrotic cells. There was also an inflammatory cell's penetration in corticular and medullary sections, stuffing of blood vessels, stretching of tubules, and constriction of Bowman's capsule space. CP-induced pathophysiological activity on the kidneys is exerted by inflammation, oxidative stress, and vasoconstriction of the renal vascular system as a result of necrosis in proximal tubule cells (Huang et al., 2017). In a previous study, tubular cell death has been reported as the principal underlying histopathological trait of renal toxicity (Oh et al., 2014). CAS attenuated the abnormalities in renal tissues and tubules in the cotreated group. These findings confirmed the anti-inflammatory and anti-oxidant action of CAS at the tissue level. This observation revealed that the therapeutic potential of CAS may be attributed to its antioxidant and anti-inflammatory properties which eventually attenuated renal tissue damages.

\section{Conclusion}

Our research showed the therapeutic capability of CAS against CP induced renal damage. The results of our investigation showed that CAS imparted a remarkable defensive role against oxidative stress and inflammation, which are a principal representative of CP-induced renal damage. CAS administration effectively mitigated the disturbance in the level of antioxidants, serum and urinary markers, inflammatory markers, and histopathological damages. This renoprotective ability of CAS is linked with its anti-oxidant, ROS scavenging, and anti-inflammatory abilities.

\section{Acknowledgements}

The authors (SM and KAG) express their sincere appreciation to the Researchers Supporting Project Number (2021/93) King Saud University, Riyadh, Saudi Arabia”.

\section{References}

ABDELLATIEF, S.A., GALAL, A.A., FAROUK, S.M. and ABDELDAIM, M.M., 2017. Ameliorative effect of parsley oil on cisplatin-induced hepato-cardiotoxicity: a biochemical, histopathological, and immunohistochemical study. Biomedicine and Pharmacotherapy, vol. 86, pp. 482-491. http://dx.doi. org/10.1016/j.biopha.2016.12.038. PMid:28012928.

ABDELSALAM, M., ELMORSY, E., ABDELWAHAB, H., ALGOHARY, O., NAGUIB, M., EL WAHAB, A.A., ELDEEB, A., ELTORABY, E., ABDELSALAM, A., SABRY, A., EL-METWALLY, M., AKL, M., ANBER, N., EL SAYED ZAKI, M., ALMUTAIRI, F. and MANSOUR, T., 2018. Urinary biomarkers for early detection of platinum-based drugs induced nephrotoxicity. BMC Nephrology, vol. 19, no. 1, pp. 219. http://dx.doi.org/10.1186/s12882-018-1022-2. PMid:30180818.

AFSAR, T., TREMBLEY, J., SALOMON, C., RAZAK, S., KHAN, M., and AHMED, K., 2016. Growth inhibition and apoptosis in cancer cells induced by polyphenolic compounds of Acacia Hydaspica: involvement of multiple signal transduction pathways. Scientific Reports, vol. 6, pp. 23077.

AITKEN, R.J. and ROMAN, S.D., 2008. Antioxidant systems and oxidative stress in the testes. Oxidative Medicine and Cellular Longevity, vol. 1, no. 1, pp. 15-24. http://dx.doi.org/10.4161/ oxim.1.1.6843. PMid:19794904.

ALI, B.H., AL MOUNDHRI, M.S., TAG ELDIN, M., NEMMAR, A. and TANIRA, M.O., 2007. The ameliorative effect of cysteine prodrug L-2-oxothiazolidine-4-carboxylic acid on cisplatin-induced nephrotoxicity in rats. Fundamental \& Clinical Pharmacology, vol. 21, no. 5, pp. 547-553. http://dx.doi.org/10.1111/j.14728206.2007.00495.x. PMid:17868208.

ALSHARARI, S.D., AL-REJAIE, S.S., ABUOHASHISH, H.M., AHMED, M.M. and HAFEZ, M.M., 2016. Rutin attenuates Hepatotoxicity in high-cholesterol-diet-fed rats. Oxidative Medicine and Cellular Longevity, vol. 2016, pp. 1-11. http://dx.doi. org/10.1155/2016/5436745. PMid:27239252.

AYDIN, B., UNSAL, M., SEKEROGLU, Z.A. and GULBAHAR, Y., 2011. The antioxidant and antigenotoxic effects of Pycnogenol on rats treated with cisplatin. Biological Trace Element Research, vol. 142, no. 3, pp.638-650. http://dx.doi.org/10.1007/s12011010-8781-3. PMid:20676799.

CARLBERG, I., and MANNERVIK, B., 1975. Purification and characterization of the flavoenzyme glutathione reductase from rat liver. Journal of Biological Chemistry, vol. 250, no. 14, pp. 5475-5480.

CHANCE, B. and MAEHLY, A.C., 1955. Assay of catalases and peroxidases. Methods in Enzymology, vol. 11, pp. 764-775. http:// dx.doi.org/10.1016/S0076-6879(55)02300-8.

CHRISTEN, P. and CUENDET, M., 2012. Plants as a source of therapeutic and health products. Chimia, vol. 66, no. 5, pp. 320-323. http://dx.doi.org/10.2533/chimia.2012.320. PMid:22867544. 
DASARI, S. and BERNARD TCHOUNWOU, P., 2014. Cisplatin in cancer therapy: molecular mechanisms of action. European Journal of Pharmacology, vol. 740, pp. 364-378. http://dx.doi. org/10.1016/j.ejphar.2014.07.025. PMid:25058905.

DEPONTE, M., 2013. Glutathione catalysis and the reaction mechanisms of glutathione-dependent enzymes. Biochimica et Biophysica Acta, vol. 1830, no. 5, pp. 3217-3266. http://dx.doi org/10.1016/j.bbagen.2012.09.018.

DIVYA, M.K., LINCY, L., RAGHAVAMENON, A.C. and BABU, T.D., 2016. Ameliorative effect of Apodytes dimidiata on cisplatin-induced nephrotoxicity in Wistar rats. Pharmaceutical Biology, vol. 54, no. 10, pp. 2149-2157. http://dx.doi.org/10.3109/13880209.20 16.1149494. PMid:26940704.

ELSHERBINY, N.M., ELADL, M.A. and AL-GAYYAR, M.M., 2016. Renal protective effects of arjunolic acid in a cisplatin-induced nephrotoxicity model. Cytokine, vol. 77, pp. 26-34. http://dx.doi. org/10.1016/j.cyto.2015.10.010. PMid:26517155.

FAIG, J., HAUGHTON, M., TAYLOR, R.C., D'AGOSTINO JUNIOR, R.B., WHELEN, M.J., POROSNICU RODRIGUEZ, K.A., BONOMI, M., MUREA, M. and POROSNICU, M., 2018. Retrospective analysis of cisplatin nephrotoxicity in patients with head and neck Cancer receiving outpatient treatment with concurrent highdose cisplatin and radiotherapy. American Journal of Clinical Oncology, vol. 41, no. 5, pp. 432-440. http://dx.doi.org/10.1097/ COC.0000000000000301. PMid:27281266.

FAROOQUI, Z., AHMED, F., RIZWAN, S., SHAHID, F., KHAN, A.A. and KHAN, F., 2017. Protective effect of Nigella sativa oil on cisplatin induced nephrotoxicity and oxidative damage in rat kidney. Biomedicine and Pharmacotherapy, vol. 85, pp. 7-15. http://dx.doi.org/10.1016/j.biopha.2016.11.110. PMid:27930989.

HABIG, W.H., PABST, M.J. and JAKOBY, W.B., 1974. GlutathioneS-transferases the first enzymatic step in mercapturic acid formation. The Journal of Biological Chemistry, vol. 249, no. 22, pp. 7130-7139. http://dx.doi.org/10.1016/S0021-9258(19)420838. PMid:4436300.

HUANG, D., WANG, C., DUAN, Y., MENG, Q., LIU, Z., HUO, X., SUN, H., MA, X. and LIU, K., 2017. Targeting Oct2 and P53: formononetin prevents cisplatin-induced acute kidney injury. Toxicology and Applied Pharmacology, vol. 326, pp. 15-24. http://dx.doi. org/10.1016/j.taap.2017.04.013. PMid:28414026.

IJAZ, M.U., ASHRAF, A., AHMED, A., ISMAIL, H., MUZZAMIL, S., SAMAD, A., AL-GHANIM, K.A., AL-MISNED, F.A., AHMED, Z. and MAHBOOB, S., 2020a. Remedial effects of casticin as an antioxidant on cisplatin induced oxidative damage in rat liver. Journal of King Saud University Science, vol. 32, no. 1, pp. 11001105. http://dx.doi.org/10.1016/j.jksus.2019.10.009.

IJAZ, M.U., TAHIR, A., SAMAD, A., ASHRAF, A., AMEEN, M., IMRAN, M., YOUSAF, S. and SARWAR, N., 2020b. Casticin Alleviates Testicular and Spermatological Damage Induced by Cisplatin in Rats. Pakistan Veterinary Journal, vol. 40, no. 2, pp. 234-238. http://dx.doi.org/10.29261/pakvetj/2019.127.

IQBAL, M., SHARMA, S.D., REZAZADEH, H., HASAN, N., ABDULLA, M. and ATHAR, M.J.R.R., 1996. Glutathione metabolizing enzymes and oxidative stress in ferric nitrilotriacetate mediated hepatic injury. Redox Report, vol. 2, no. 6, pp. 385-391. http://dx.doi.or g/10.1080/13510002.1996.11747079. PMid:27406673.

JOLLOW, D.J., MITCHELL, J., ZAMPAGLIONE, N.A. and GILLETTE, J., 1974. Bromobenzene-induced liver necrosis. Protective role of glutathione and evidence for 3, 4-bromobenzene oxide as the hepatotoxic metabolite. Pharmacology, vol. 11, no. 3, pp. 151-169. http://dx.doi.org/10.1159/000136485. PMid:4831804.

KAKKAR, P., DAS, B. and VISWANATHAN, P.N., 1984. A modified spectrophotometric assay of superoxide dismutase. Indian
Journal of Biochemistry \&' Biophysics, vol. 21, no. 2, pp. 130-132. PMid:6490072.

KANDEMIR, F.M., YILDIRIM, S., KUCUKLER, S., CAGLAYAN, C., MAHAMADU, A. and DORTBUDAK, M.B., 2018. Therapeutic efficacy of zingerone against vancomycin-induced oxidative stress, inflammation, apoptosis and aquaporin 1 permeability in rat kidney. Biomedicine and Pharmacotherapy, vol. 105, pp. 981-991. http://dx.doi.org/10.1016/j.biopha.2018.06.048. PMid:30021393.

KANEKO, T., IUCHI, Y., KOBAYASHI, T., FUJII, T., SAITO, H., KURACHI, H. and FUJII, J., 2002. The expression of glutathione reductase in the male reproductive system of rats supports the enzymatic basis of glutathione function in spermatogenesis. European Journal of Biochemistry, vol. 269, no. 5, pp. 1570-1578. http:// dx.doi.org/10.1046/j.1432-1033.2002.02809.x. PMid:11874473.

KHAN, R., KHAN, A.Q., QAMAR, W., LATEEF, A., ALI, F., REHMAN, M.U., TAHIR, M., SHARMA, S. and SULTANA, S., 2012. Chrysin abrogates cisplatin-induced oxidative stress, p53 expression, goblet cell disintegration and apoptotic responses in the jejunum of Wistar rats. The British Journal of Nutrition, vol. 108, no. 9, pp. 1574-1585. http://dx.doi.org/10.1017/S0007114511007239. PMid:22309980.

KHAN, R.A., KHAN, M.R., SAHREEN, S. and BOKHARI, J., 2010. Prevention of CCl4-induced nephrotoxicity with Sonchus asper in rat. Food and Chemical Toxicology, vol. 48, no. 8, pp. 2469-2476. http://dx.doi.org/10.1016/j.fct.2010.06.016. PMid:20550952.

KRUGER, P., SAFFARZADEH, M., WEBER, A.N., RIEBER, N., RADSAK, M., VON BERNUTH, H., BENARAFA, C., ROOS, D., SKOKOWA, J. and HARTL, D., 2015. Neutrophils: Between Host Defence, Immune Modulation, and Tissue Injury. PLoS Pathogens, vol. 11, no. 3, pp. e1004651. http://dx.doi.org/10.1371/journal. ppat.1004651. PMid:25764063.

KUMAR, P., SULAKHIYA, K., BARUA, C.C. and MUNDHE, N., 2017. TNF-alpha, IL-6 and IL-10 expressions, responsible for disparity in action of curcumin against cisplatin-induced nephrotoxicity in rats. Molecular and Cellular Biochemistry, vol. 431, no. 1-2, pp. 113-122. http://dx.doi.org/10.1007/s11010-017-2981-5. PMid:28258441.

LEE, M.T., LIN, W.C., YU, B. and LEE, T.T., 2017. Antioxidant capacity of phytochemicals and their potential effects on oxidative status in animals. Asian-Australasian Journal of Animal Sciences, vol. 30, no. 3, pp. 299-308. http://dx.doi.org/10.5713/ajas.16.0438. PMid:27660026.

LEE, S., KIM, W., MOON, S.O., SUNG, M.J., KIM, D.H., KANG, K.P., JANG, Y.B., LEE, J.E., JANG, K.Y. and PARK, S.K., 2006. Rosiglitazone ameliorates cisplatin-induced renal injury in mice. Nephrology, Dialysis, Transplantation, vol. 21, no. 8, pp. 2096-2105. http:// dx.doi.org/10.1093/ndt/gfl194. PMid:16728429.

LEI, L., LI, L.P., ZENG, Z., MU, J.X., YANG, X., ZHOU, C., WANG, Z.L. and ZHANG, H., 2018. Value of urinary KIM-1 and NGAL combined with serum Cys $\mathrm{C}$ for predicting acute kidney injury secondary to decompensated cirrhosis. Scientific Reports, vol. 8, no. 1, pp. 7962. http://dx.doi.org/10.1038/s41598-018-26226-6. PMid:29784944.

LIOCHEV, S.I. and FRIDOVICH, I., 2010. Mechanism of the peroxidase activity of $\mathrm{Cu}, \mathrm{Zn}$ superoxide dismutase. Free Radical Biology E' Medicine, vol. 48, no. 12, pp. 1565-1569. http://dx.doi. org/10.1016/j.freeradbiomed.2010.02.036. PMid:20211248.

LUO, Q.H., CHEN, M.L., CHEN, Z.L., HUANG, C., CHENG, A.C., FANG, J., TANG, L. and GENG, Y., 2016. Evaluation of KIM-1 and NGAL as early indicators for assessment of gentamycininduced nephrotoxicity in vivo and in vitro. Kidney $\&$ Blood Pressure Research, vol. 41, no. 6, pp. 911-918. http://dx.doi. org/10.1159/000452592. PMid:27889773. 
MA, Z.-N., LI, Y.-Z., LI, W., YAN, X.-T., YANG, G., ZHANG, J., ZHAO, C. and YANG, L.-M., 2017. Nephroprotective effects of saponins from leaves of Panax quinquefolius against cisplatin-induced acute kidney injury. International Journal of Molecular Sciences, vol. 18, no. 7, pp. 1407. http://dx.doi.org/10.3390/ijms18071407. PMid:28703736.

MALI, R.G. and DHAKE, A.S., 2011. A review on herbal antiasthmatics. Oriental Pharmacy and Experimental Medicine, vol. 11, no. 2, pp. 77-90. http://dx.doi.org/10.1007/s13596-011-0019-1. PMid:22207824.

MALIK, S., SUCHAL, K., BHATIA, J., KHAN, S.I., VASISTH, S., TOMAR, A., GOYAL, S., KUMAR, R., ARYA, D.S. and OJHA, S.K., 2016. Therapeutic potential and molecular mechanisms of Emblica officinalis Gaertn in countering Nephrotoxicity in rats induced by the chemotherapeutic agent Cisplatin. Frontiers in Pharmacology, vol. 7, pp. 350. http://dx.doi.org/10.3389/fphar.2016.00350. PMid:27752245.

MIYAHISA, I., FUNA, N., OHNISHI, Y., MARTENS, S., MORIGUCHI, T. and HORINOUCHI, S., 2006. Combinatorial biosynthesis of flavones and flavonols in Escherichia coli. Applied Microbiology and Biotechnology, vol. 71, no. 1, pp. 53-58. http://dx.doi. org/10.1007/s00253-005-0116-5. PMid:16133333.

MORI, K., LEE, H.T., RAPOPORT, D., DREXLER, I.R., FOSTER, K., YANG, J., SCHMIDT-OTT, K.M., CHEN, X., LI, J.Y., WEISS, S., MISHRA, J., CHEEMA, F.H., MARKOWITZ, G., SUGANAMI, T., SAWAI, K., MUKOYAMA, M., KUNIS, C., D’AGATI, V., DEVARAJAN, P. and BARASCH, J., 2005. Endocytic delivery of lipocalin-siderophoreiron complex rescues the kidney from ischemia-reperfusion injury. The Journal of Clinical Investigation, vol. 115, no. 3, pp. 610-621. http://dx.doi.org/10.1172/JCI23056. PMid:15711640.

MUKHOPADHYAY, P., HORVATH, B., ZSENGELLER, Z., ZIELONKA, J., TANCHIAN, G., HOLOVAC, E., KECHRID, M., PATEL, V., STILLMAN, I.E., PARIKH, S.M., JOSEPH, J., KALYANARAMAN, B. and PACHER, P., 2012. Mitochondrial-targeted antioxidants represent a promising approach for prevention of cisplatin-induced nephropathy. Free Radical Biology \& Medicine, vol. 52, no. 2, pp. 497-506. http:// dx.doi.org/10.1016/j.freeradbiomed.2011.11.001. PMid:22120494.

OH, G.S., KIM, H.J., SHEN, A.H., LEE, S.B., KHADKA, D., PANDIT, A. and SO, H.S., 2014. Cisplatin-induced kidney dysfunction and perspectives on improving treatment strategies. Electrolyte $\mathcal{E}$ Blood Pressure, vol. 12, no. 2, pp. 55-65. http://dx.doi.org/10.5049/ EBP.2014.12.2.55. PMid:25606044.

OH, C.J., HA, C.M., CHOI, Y.K., PARK, S., CHOE, M.S., JEOUNG, N.H., HUH, Y.H., KIM, H.J., KWEON, H.S., LEE, J.M., LEE, S.J., JEON, J.H., HARRIS, R.A., PARK, K.G. and LEE, I.K., 2017a. Pyruvate dehydrogenase kinase 4 deficiency attenuates cisplatininduced acute kidney injury. Kidney International, vol. 91, no. 4, pp. 880-895. http://dx.doi.org/10.1016/j.kint.2016.10.011. PMid:28040265.

OH, S.M., PARK, G., LEE, S.H., SEO, C.S., SHIN, H.K. and OH, D.S., 2017b. Assessing the recovery from prerenal and renal acute kidney injury after treatment with single herbal medicine via activity of the biomarkers HMGB1, NGAL and KIM-1 in kidney proximal tubular cells treated by cisplatin with different doses and exposure times. BMC Complementary and Alternative Medicine, vol. 17, no. 1, pp. 544. http://dx.doi.org/10.1186/ s12906-017-2055-y. PMid:29258482.

OMAR, G., ABDALLAH, L., BARAKAT, A., OTHMAN, R. and BOURINEE, H., 2020. In vitro haemostatic efficacy of aqueous, methanol and ethanol plant extracts of three medicinal plant species in Palestine. Brazilian Journal of Biology = Revista Brasileira de Biologia, vol. 80, no. 4, pp. 763-768. http://dx.doi. org/10.1590/1519-6984.219186. PMid:31800761.
PABLA, N. and DONG, Z., 2008. Cisplatin nephrotoxicity: mechanisms and renoprotective strategies. Kidney International, vol. 73, no. 9, pp. 994-1007. http://dx.doi.org/10.1038/sj.ki.5002786. PMid:18272962.

PEDRAZA-CHAVERRI, J., BARRERA, D., MALDONADO, P.D., CHIRINO, Y.I., MACIAS-RUVALCABA, N.A., MEDINA-CAMPOS, O.N., CASTRO, L., SALCEDO, M.I. and HERNANDEZ-PANDO, R., 2004. S-allylmercaptocysteine scavenges hydroxyl radical and singlet oxygen in vitro and attenuates gentamicin-induced oxidative and nitrosative stress and renal damage in vivo. BMC Clinical Pharmacology, vol. 4, no. 1, pp. 5. http://dx.doi.org/10.1186/14726904-4-5. PMid:15119956.

PERAZELLA, M.A., 2012. Onco-nephrology: renal toxicities of chemotherapeutic agents. Clinical Journal of the American Society of Nephrology: CJASN, vol. 7, no. 10, pp. 1713-1721. http://dx.doi. org/10.2215/CJN.02780312. PMid:22879440.

PICK, E. and KEISARI, Y., 1981. Superoxide anion and hydrogen peroxide production by chemically elicited peritoneal macrophages induction by multiple nonphagocytic stimuli. Cellular Immunology, vol. 59, no. 2, pp. 301-318. http://dx.doi. org/10.1016/0008-8749(81)90411-1. PMid:6269759.

RAMESH, G., ZHANG, B., UEMATSU, S., AKIRA, S. and REEVES, W.B., 2007. Endotoxin and cisplatin synergistically induce renal dysfunction and cytokine production in mice. American Journal of Physiology. Renal Physiology, vol. 293, no. 1, pp. F325-F332. http://dx.doi.org/10.1152/ajprenal.00158.2007. PMid:17494092.

REGGINATO, A., CUNICO, L., BERTONCELLO, K.T., SCHINDLER, M.S.Z., CHITOLINA, R., MARINS, K., ZANATTA, A.P., CALISTO, J.F., OLIVEIRA, J.V., MAGRO, J.D. and ZANATTA, L., 2021. Antidiabetic and hypolipidemic potential of Campomanesia xanthocarpa seed extract obtained by supercritical CO2. Brazilian Journal of Biology = Revista Brasileira de Biologia, vol. 81, no. 3, pp. 621-631. http://dx.doi.org/10.1590/1519-6984.227388. PMid:32876168.

ROSS, J.A. and KASUM, C.M., 2002. Dietary flavonoids: bioavailability, metabolic effects, and safety. Annual Review of Nutrition, vol. 22, pp. 19-34. http://dx.doi.org/10.1146/annurev. nutr.22.111401.144957. PMid:12055336.

SAHREEN, S., KHAN, M.R., KHAN, R.A. and ALKREATHY, H.M., 2015. Protective effects of Carissa opaca fruits against CCl4-induced oxidative kidney lipid peroxidation and trauma in rat. Food E' Nutrition Research, vol. 7, no. 59, pp. 28438. http://dx.doi. org/10.3402/fnr.v59.28438. PMid:26350293.

SAHU, B.D., RENTAM, K.K.R., PUTCHA, U.K., KUNCHA, M., VEGI, G.M.N. and SISTLA, R., 2011. Carnosic acid attenuates renal injury in an experimental model of rat cisplatin-induced nephrotoxicity. Food and Chemical Toxicology, vol. 49, no. 12, pp. 3090-3097. http://dx.doi.org/10.1016/j.fct.2011.08.018. PMid:21930180.

SARAL, S., OZCELIK, E., CETIN, A., SARAL, O., BASAK, N., AYDIN, M. and CIFTCI, O., 2016. Protective role of Diospyros lotus on cisplatin-induced changes in sperm characteristics, testicular damage and oxidative stress in rats. Andrologia, vol. 48, no. 3, pp. 308-317. http://dx.doi.org/10.1111/and.12448. PMid:26173854.

SATOH, M., KASHIHARA, N., FUJIMOTO, S., HORIKE, H., TOKURA, T., NAMIKOSHI, T., SASAKI, T. and MAKINO, H., 2003. Asa novel free radical scavenger, edarabone, protects against cisplatininduced acute renal damage in vitro and in vivo. The Journal of Pharmacology and Experimental Therapeutics, vol. 305, no. 3, pp. 1183-1190. http://dx.doi.org/10.1124/jpet.102.047522. PMid:12649298.

SHIN, E.K., KWON, H.S., KIM, Y.H., SHIN, H.K. and KIM, J.K., 2009. Chrysin, a natural flavone, improves murine inflammatory bowel diseases. Biochemical and Biophysical Research Communications, vol. 381, no. 4, pp. 502-507. http://dx.doi.org/10.1016/j. bbrc.2009.02.071. PMid:19233127. 
SUBBARAMAIAH, K. and DANNENBERG, A.J., 2003. Cyclooxygenase 2: a molecular target for cancer prevention and treatment. Trends in Pharmacological Sciences, vol. 24, no. 2, pp. 96-102. http:// dx.doi.org/10.1016/S0165-6147(02)00043-3. PMid:12559775.

TERADA, Y., INOUE, K., MATSUMOTO, T., ISHIHARA, M., HAMADA, K. SHIMAMURA, Y., OGATA, K., INOUE, K., TANIGUCHI, Y., HORINO, T., KARASHIMA, T., TAMURA, K., FUKUHARA, H., FUJIMOTO, S., TSUDA, M. and SHUIN, T., 2013. 5-Aminolevulinic acid protects against cisplatin-induced nephrotoxicity without compromising the anticancer efficiency of cisplatin in rats in vitro and in vivo. PLoS One, vol. 8, no. 12, pp. 808-850. http://dx.doi.org/10.1371/ journal.pone.0080850. PMid:24324635.
TIRMENSTEIN, M.A. and REED, D.J., 1989. Role of partially purified glutathione S-transferase from rat liver nuclei in the inhibition of nuclear lipid peroxidation. Biochimica et Biophysica Acta, vol. 995, no. 2, pp. 174-180. http://dx.doi.org/10.1016/01674838(89)90077-0. PMid:2930795.

TUCKER, B.M. and PERAZELLA, M.A., 2018. Medications. In: E.V. LERMA, M.A. SPARKS and J. TOPF, eds. Nephrology secrets. 4th ed. Philadelphia, PA: Elsevier, pp. 78-83.

YANG, F., LONG, F., XUECHUAN, H., XUEQIN, L., HONGYUN, M. and YONGHUI, D., 2015. Upregulation of Fas in epithelial ovarian cancer reverses the development of resistance to Cisplatin. BMB Reports, vol. 48, no. 1, pp. 30-35. http://dx.doi.org/10.5483/ BMBRep.2015.48.1.042. PMid:24755555. 